\title{
The Level of Inquiry among Preservice Biology Teachers
}

\author{
Aynin Mashfufah ${ }^{1, *}$, Joko Nurkamto ${ }^{1}$, Sajidan Sajidan ${ }^{1}$, Wiranto Wiranto ${ }^{2}$ \\ ${ }^{1}$ Department of Educational Science, Faculty of Teacher Training and Education, Sebelas Maret University, Indonesia \\ ${ }^{2}$ Department of Informatics of Science, Faculty of Math and Science, Sebelas Maret University, Indonesia
}

Received December 9, 2019; Revised December 30, 2019; Accepted February 25, 2020

Copyright $(2020$ by authors, all rights reserved. Authors agree that this article remains permanently open access under the terms of the Creative Commons Attribution License 4.0 International License

\begin{abstract}
Inquiry-based learning becomes a necessity to fulfill 21 st-century learning. The students are expected to be able to respond toward all changes around them and are skilled at solving problems in daily life. However, what is the mastery level of each inquiry cycle by biology preservice teachers? They need to master a variety of inquiry skills. Thus, they have the readiness to present their students' meaningful learning experiences through problem-oriented learning. The purpose of the study is to find out the mastery level of sixth levels of inquiry, which adapts from Wenning. The research method used is survey techniques. The questionnaire consists of the description of five stages on the sixth-level of inquiry. Participants required to choose Yes or No option if he/she does or not the step along with inquiry-based learning. Involved participants are 65 preservice biology teachers. Further research is developing the learning strategy based on the level of inquiry. The result shows that discovery learning and interactive demonstration at a high level, inquiry lesson and inquiry laboratory at the middle level, and Real-world application and hypothetical inquiry at the low level.
\end{abstract}

Keywords Inquiry-Based Learning, the Level of inquiry, Mastery Level

\section{Introduction}

Education should be bridge what students learn at school and their lives. A student who can make a connection between theory and practice would be able to socialize effectively. The student spends their experiences with many challenges and changes. Hence, they need to adapt and survive. Also, to achieve knowledge, the student needs skills to respond, analyze, and solve the problem. These are information and communication, thinking and problem-solving, interpersonal, and self-directional ability [1].

Experience-based learning through real-world examples and applications facilitates students to get meaningful learning [2]. Meaningful learning needs to concern how the learned concept and gained experience in the school could be applied in the student's daily lives and become lifelong education [3]. Meaningful learning emphasizes student-centered learning through social relations and multiple social roles and process-based assessment [4]. The teacher has to create a learning setting, a more authentic -learning place with an authentic situation [5].

Inquiry-based teaching assists the student in gaining observation, deduction, and experimentation skills [6]. The inquiry that is initiated by the student by leading question leads to empower their critical thinking to investigate the phenomenon and produces new knowledge such as scientist's work. Also, it provides with a deep understanding of science [7]. Leading question drives a student to identify their prior experience and make a connection between long and short term working memory in response to problems [8].

The study focuses on the profile of the mastery level of inquiry to inform what kinds of science process skills are owned by an individual and preservice biology teachers' engagement during inquiry instruction. The importance of this study is to consider how the design of learning and instruction will be. There is a lot of misconception about inquiry-based learning. Furthermore, this paper will be a reference about how the characteristics, the syntax of, and the specific pedagogical purposes of each level of inquiry.

\subsection{Literature Review}

According to the previous researches about inquiry learning cycle, [9] have grouped the phase of inquiry-based learning into three pathways: (1) Orientation - Questioning - Exploration - Questioning Exploration - Data Interpretation - Conclusion, (2) 
Orientation - Hypothesis Generation - Experimentation Data Interpretation - Hypothesis Generation Experimentation - Data Interpretation - Conclusion, and (3) Orientation - Questioning - Hypothesis Generation Experimentation - Data Interpretation - (Questioning) Hypothesis Generation - Experimentation - Data Interpretation - Conclusion.

The development of inquiry levels is based on the learning experiences of John Dewey. Obtained knowledge plays as an impulse to begin another cycle of learning. Student builds up their expertise and enhances scientific literacy. Inquiry levels, which consist of five cycles that are observation, manipulation, generalization, verification, and application, encourage the student to comprehensively conduct the scientist's work on discovering the new knowledge. Furthermore, the student obtains their intellectual sophistication through scientific process skills [10].

\subsubsection{Levels of Inquiry}

There are six levels of inquiry, which are discovery learning, interactive demonstration, inquiry lesson, inquiry labs, real-world application, and hypothetical inquiry [11]. Each level of inquiry has a specific pedagogical purpose. Discovery learning emphasizes students to engage actively in constructing new knowledge through first-hand experiences. Interactive demonstrations force a student to present their prior knowledge, and it's used to predict during the demonstration. Inquiry lesson facilitates student to make a connection between scientific principles to produce more detailed understanding. Inquiry laboratory allows the student to their independently variable testing to create new principles, empirical laws, or knowledge. Real-world applications address students to actively solve the problem in a real situation through a problem or project-based learning. Hypothetical inquiry engages the student to generate an explanation for observed phenomena [12]. The following table 1 describes the differences among the six levels of inquiry learning cycle [11].

Table 1. The significant differences between the six levels of inquiry

\begin{tabular}{|c|c|c|c|c|c|}
\hline $\begin{array}{c}\text { Discovery } \\
\text { learning }\end{array}$ & $\begin{array}{c}\text { Interactive } \\
\text { demonstration }\end{array}$ & Inquiry lesson & $\begin{array}{c}\text { Inquiry } \\
\text { laboratory }\end{array}$ & $\begin{array}{c}\text { Real-world } \\
\text { application }\end{array}$ & $\begin{array}{c}\text { Hypothetical } \\
\text { inquiry }\end{array}$ \\
\hline Lower & \multicolumn{4}{|c|}{ Intellectual sophistication } & High \\
\hline Teacher & - & \multicolumn{2}{|c|}{ Locus of control } & Student \\
\hline $\begin{array}{c}\text { Rudimentary } \\
\text { skills }\end{array}$ & Basic skills & $\begin{array}{c}\text { Intermediate } \\
\text { skills }\end{array}$ & Integrated skill & Culminating skills & Advanced skills \\
\hline
\end{tabular}

Table 2. Intellectual process skills

\begin{tabular}{|c|c|c|c|c|c|}
\hline $\begin{array}{c}\text { Discovery } \\
\text { learning }\end{array}$ & $\begin{array}{c}\text { Interactive } \\
\text { demonstration }\end{array}$ & Inquiry lesson & Inquiry lab & Real-world application & $\begin{array}{l}\text { Hypothetical } \\
\text { inquiry }\end{array}$ \\
\hline $\begin{array}{l}\text { Rudimentary } \\
\text { skills }\end{array}$ & Basic skills & Intermediate skills & Integrated skills & Culminating skills & Advanced skills \\
\hline $\begin{array}{ll}\text { - } & \text { observing } \\
\text { - } & \text { formulating } \\
\text { concepts } \\
\text { - } & \text { estimating } \\
\text { - } & \text { making the } \\
\text { conclusion } \\
\text { - } \\
\text { sharing } \\
\text { results } \\
\text { classifying } \\
\text { results }\end{array}$ & $\begin{array}{ll}\text { - } & \text { predicting } \\
\text { - } & \text { explaining } \\
\text { - } & \text { estimating } \\
\text { obtaining and } \\
\text { processing } \\
\text { data } \\
\text { formulating } \\
\text { and revising } \\
\text { scientific } \\
\text { explanation } \\
\text { using logic } \\
\text { and evidence } \\
\text { recognizing } \\
\text { and } \\
\text { analyzing } \\
\text { alternative } \\
\text { explanation } \\
\text { and models }\end{array}$ & $\begin{array}{ll}\text { - } & \text { measuring } \\
\text { collecting } \\
\text { data } \\
\text { - } \\
\text { constructing } \\
\text { a data table } \\
\text { designing } \\
\text { and } \\
\text { conducting a } \\
\text { scientific } \\
\text { investigation } \\
\text { using } \\
\text { technology } \\
\text { and math } \\
\text { during } \\
\text { studies } \\
\text { describing } \\
\text { the } \\
\text { relationship }\end{array}$ & $\begin{array}{l}\text { - designing } \\
\text { and } \\
\text { conducting } \\
\text { a scientific } \\
\text { investigatio } \\
\mathrm{n} \\
\text { - } \text { measuring } \\
\text { metrically } \\
\text { using } \\
\text { technology } \\
\text { and math } \\
\text { during the } \\
\text { investigatio } \\
\mathrm{n} \\
\text { establishing } \\
\text { empirical } \\
\text { laws based } \\
\text { on } \\
\text { evidence } \\
\text { and logic }\end{array}$ & 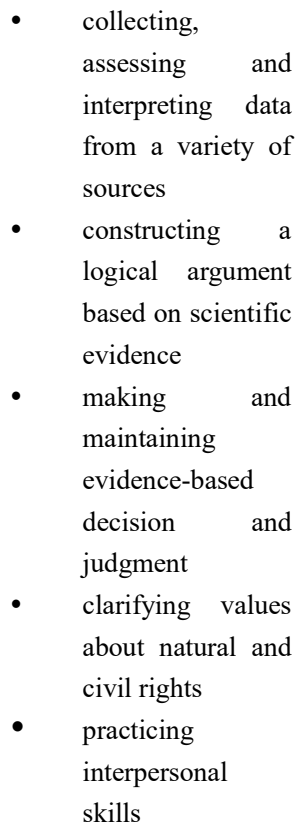 & 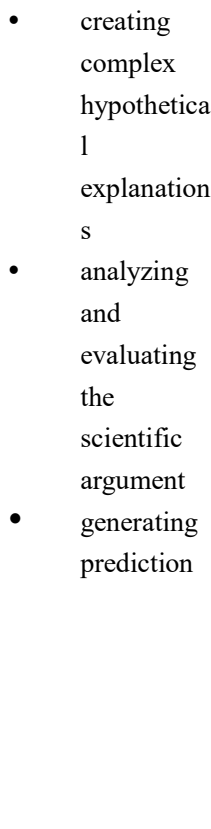 \\
\hline
\end{tabular}




\subsubsection{Skills of Each Level of Inquiry}

As table 1 shows, the higher the level of inquiry, the more complex skills mastered, the higher intellectuality, the shifted control from teacher to student, and the increased independence of students in determining the direction of investigation [13]. For example, when students achieved the level of inquiry lab and learn about environmental science, especially for ecological damage and its solution, they need to be able to make their design of investigation started from the leading question. That question navigates students to identify problems to investigate, designing and conducting a scientific inquiry, using technology and math during the investigation, generating principles through the process of induction, and sharing the result of investigation through discussion and maintain the evidence-based argument. The table 2 presents the intellectual process skills for each level of inquiry [14].

Intellectual process skills allow the student to obtain a meaningful learning experience because they engage in scientific investigation to generate scientific evidence and construct new knowledge [15]. Presenting the question, planning and designing experiments, collecting and analyzing data, and making the conclusion based on evidence facilitates students to acquire intellectual ownership [7]. Student who evolves in science-oriented problems lead to a scientific argument which is supported by the evidence through the investigation. Scientific inquiry shows how to generate knowledge and allows the student to understand the nature of science [16] [17].

\section{Materials and Methods}

For this quantitative study, a questionnaire adapted from [10] [12] was delivered to 65 preservice biology teachers. The instrument consists of a description of five stages of each level of inquiry, which is developed by [18]. There are six levels of inquiry including observation, manipulation, generalization, verification, and application. Respondent asked to choose whether he/ she conduct the stage in each level of inquiry or not. Data were analyzed descriptively based on the percentage of individual score/total score. There are three categories of inquiry mastery level, low $(<30 \%)$, mediate $(30 \%-70 \%)$, and high (71\%-100\%). Also, the level of preservice biology teachers' participation is grouped into five rating scales, not active at all $(<20 \%)$, less active $(20-39 \%)$, active enough $(40-59 \%)$, active $(60-79 \%)$, and very active $(80-100 \%)$.

\section{Findings}

\subsection{The Mastery of Inquiry Level}

Measuring the ability of inquiry level essentially needs an assessment before developing learning activity, which integrates a particular level of inquiry. The teacher or lecturer could identify preservice biology teachers' intellectual process skills. The following table 3 is the mastery level of a preservice biology teacher. According to this table, the higher the level of inquiry, the lower the level of its mastery.

Table 3. Level of inquiry among preservice biology teachers

\begin{tabular}{|l|l|}
\hline Level of inquiry & Level of mastery (\%) \\
\hline Discovery learning & 73,5 \\
\hline Interactive demonstration & 73,2 \\
\hline Inquiry lesson & 70,5 \\
\hline Inquiry lab & 58,1 \\
\hline Real-world application & 28,9 \\
\hline Hypothetical inquiry & 27,07 \\
\hline
\end{tabular}

\subsection{Preservice Biology Teacher Engagement during Instruction}

The inquiry cycle consists of five stages, that are observation, manipulation, generalization, verification, and application. The fifth stages have a different description depending on the level of inquiry. The higher the level of inquiry, the higher the level of intellectual process skills. The following table 4 presents what percentage of preservice biology teachers' engagement for each step in the inquiry cycle.

Table 4. Percentage of preservice biology teachers engagement on each step of the inquiry cycle

\begin{tabular}{|c|c|c|c|c|c|c|}
\hline \multirow[b]{2}{*}{ Syntax/step } & \multicolumn{6}{|c|}{ Percentage $(\%)$} \\
\hline & $\begin{array}{c}\text { Discovery } \\
\text { learning }\end{array}$ & $\begin{array}{c}\text { Interactive } \\
\text { demonstration }\end{array}$ & $\begin{array}{l}\text { Inquiry } \\
\text { lesson }\end{array}$ & Inquiry lab & $\begin{array}{l}\text { Real-world } \\
\text { application }\end{array}$ & $\begin{array}{c}\text { Hypothetical } \\
\text { inquiry }\end{array}$ \\
\hline Observation & 100 & 100 & 100 & 75,3 & 29,2 & 27,6 \\
\hline Manipulation & 100 & 100 & 96,9 & 63 & 29,2 & 29,2 \\
\hline Generalization & 73,8 & 72,3 & 60 & 61,5 & 32,3 & 33,8 \\
\hline Verification & 58,4 & 58,4 & 58,4 & 58,4 & 36,9 & 9,6 \\
\hline Application & 35,3 & 35,3 & 35,3 & 32,3 & 16,9 & 2,7 \\
\hline
\end{tabular}


At the first level, the preservice biology teachers are actively engaged in observation, manipulation, generalization, and verification. The preservice biology teacher fully participates within a group, especially on object observation and description, then makes a connection between two observed objects temporarily and confirms the conclusion through classical discussion. However, when a student comes to the application step, they tend to involve less. For the second level, the preservice biology teachers' have the same tendency with the first level of inquiry. Otherwise, when a preservice biology teacher needs to build a conclusion of the demonstration, some preservice biology teachers are less actively and waiting for their group to finish this step.

During the level of inquiry lesson, preservice biology teachers' engagement starts to decrease at manipulation. Some preservice biology teachers, are not sufficiently interested and take part to plan and conduct experiments, and then analyze the data. The lowering of preservice biology teachers' participation is very sharp when they have to conclude the result of the experiment. That condition is followed by a limited prediction of the problem that would arise dealing with the founded previous concept. The preservice biology teachers still have less concern to extend the next experiment based on the earlier concepts.

Inquiry lab demands a preservice biology teacher to involve in the scientific investigation on their strategy actively. However, there are less preservice biology teachers to engage starting from observation until application. The percentage of involvement tends to decrease very sharp from observation until generalization. It seems that there is a constant engagement of preservice biology teachers at the verification stage.

Real-world application and hypothetical inquiry show the same response from the preservice biology teachers, who are less involved during observation until generalization. However, preservice biology teachers are more passively to participate in verification and application. At the real-world application and hypothetical inquiry, the preservice biology teachers tend to show their difficulties in identifying and presenting the problem, which determines the next plan to experiment. Also, making a relationship between conducted experiments and their daily life is likely to be a serious follow-up. The student has a limited ability to evaluate and revise the previous experiment to get a more effective procedure.

According to the result description, the summary of preservice biology teachers' participation shows the decreasing pattern toward an increasing level of inquiry as to the following figure 1 . It reveals that only the verification stage is almost constant for the fourth level of inquiry.

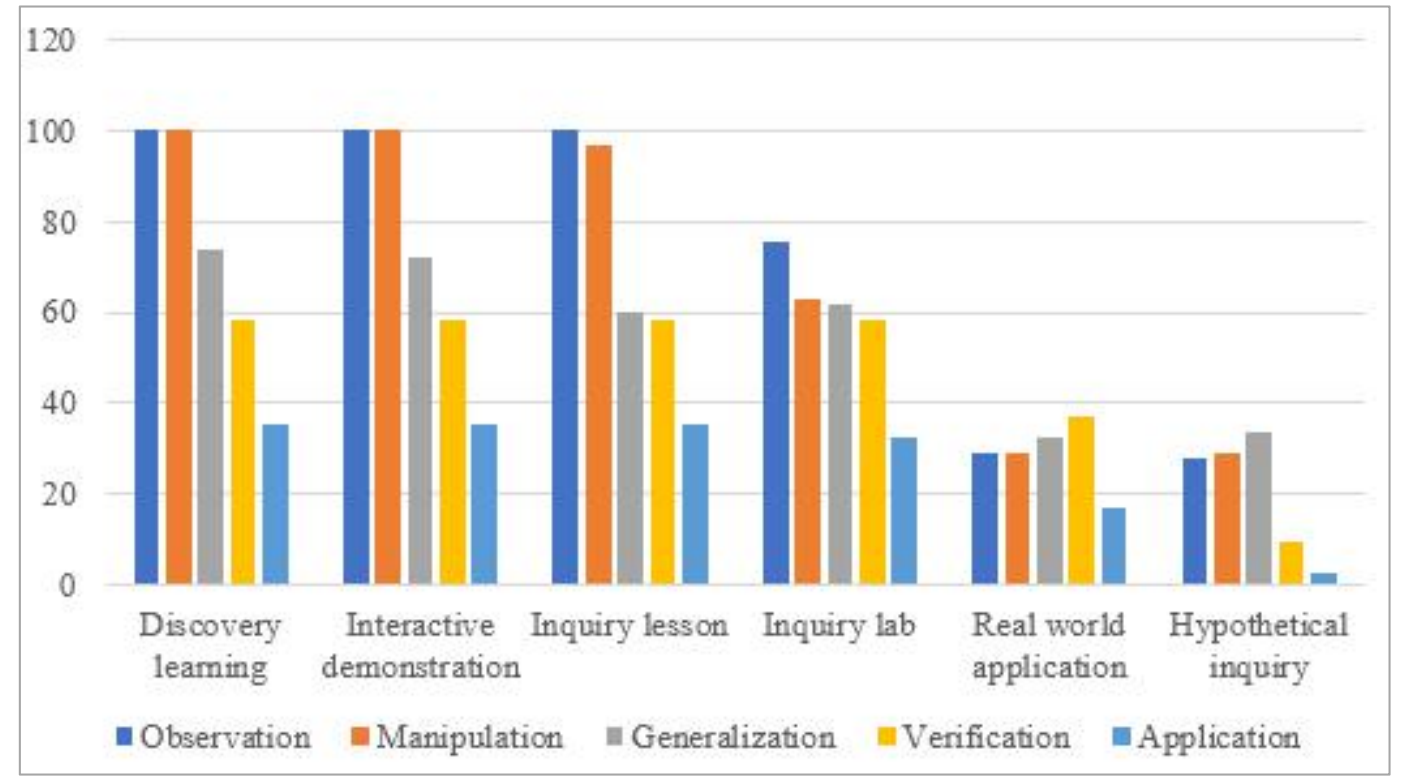

Figure 1. The pattern of student engagement on five steps of inquiry level 
Inquiry instruction, which is designed appropriately with considerable time and effort, will contribute toward student achievement through a variety of scientific activities [19]. However, the recent study shows that inquiry-based instruction with a heavy cognitive load tends to be less effective in obtaining students' achievement besides students' socioeconomic status [20].

According to the result of the survey, it seems that the higher level of inquiry, the lower its mastery among preservice biology teachers. It is related to the result of student engagement along the inquiry cycle. The student actively participated in identifying the problem, planned the investigation, and generated the conclusion. However, they tend to be less active when they are promoted to the application stage. That condition deal with the previous study, which is student more actively involved in knowing and reasoning [21]. Presenting the question and withhold the answer is a key to promote students to conduct a scientific investigation. However, facilitating learning while addressing the solution through the investigation contributes to minimizing the students' resistance toward inquiry-based instruction [22].

As the previous explanation, there is an increase of intellectual sophistication required to the higher level of inquiry and the more independent student to control their inquiry activities [12]. The inclination of the higher level of inquiry, the lower its mastery level related to the kind of students' knowledge, such as declarative knowledge, procedural knowledge, situational knowledge, and strategic knowledge. Poor performers are only oriented to declarative knowledge such as facts, definitions, and descriptions, whereas good performers pay attention to procedural and situational knowledge, such as to conduct a manipulation after address the problems. Thus, to be a good investigator, the student needs to gain and combine the three kinds of knowledge which are declarative, situational, and procedural knowledge [8].

Observation has a higher percentage of student engagement than other stages within the inquiry cycle. A leading question from the teacher still dominates this stage to navigate the more in-depth investigation about the exciting phenomenon [12]. Students building communication through their community to acquire new knowledge and combine it with the prior experience then produce skills [23]. Observation helps the student to identify the appropriate problem and prove them. The problem complexity at discovery learning, interactive demonstration, and inquiry lesson is less than the next three levels of inquiry. Consequently, they are far from frustrated thinking and less engagement [24].

Manipulation leads to a decrease from inquiry lessons to the hypothetical inquiry. Associated with the performance skills, these four levels of inquiry directly to a heavy cognitive load, such as designing and evaluating the scientific investigation, measuring, collecting data, constructing a logical argument, and maintaining evidence-based scientific argument [18]. A heavy cognitive load has an impact on performance dropped [21]. The higher level of inquiry requires the independent work of the student and intellectual sophistication.

Generalization includes making a deductive conclusion from the investigation to establish new principles or empirical laws. Generalization is resulted from collecting and summarizing the data. Without actively student's participation within the scientific investigation, fewer students can construct the generalization. Passively investigation affects students from missing analysis and invalidates generalization [25]. What students have learned, like prior knowledge, and mathematical skills contribute to establishing the generalization? However, doing work actively, paying attention, and motivation are very crucial to a deeper understanding of problem investigation [26].

Verification allows the student to communicate the result of the investigation and sustain their evidence-based argument. This stage includes reasoning skills, how a student makes a comprehensive connection of problem identified, data explanation and summarizing, and the theory, which student have learned [27]. Nevertheless, there is a more knowledgeable student who takes involvement consistently during inquiry activities could give an appropriate corroboration [26].

The application employs several activities such as the construction of the concepts or knowledge from experience, applying the prior knowledge to problem-solving [18]. Also, application is related to utilizing the learned ideas along inquiry cycles. That ideas show the relevance, meaningfulness, and mastery of contents and skills [28]. The result shows that there is an inclination of student discouragement at application. Less participation could lead to the low ability of content as well as skills to solve the problem within the new situation. Interactivity, hands-on investigation, and individualized learning experiences contribute to encouraging at application stage actively [18].

\section{Conclusions}

The mastery level of inquiry among preservice biology teachers is spread from high until low level. Discovery learning, interactive demonstration, and inquiry lesson are at a high level (more than $70 \%$ ), with inquiry laboratory at a moderate level (30-70\%), and real-world application and hypothetical inquiry at a low level (less than $30 \%$ ). That percentage supported by the tendency which is the higher level of inquiry, the lower the level of its mastery. Besides, the more complex the inquiry level, the lower the student engagement.

\section{Acknowledgments}

The researcher is very grateful to the LPDP for supporting the research funding. 


\section{REFERENCES}

[1] P 21 (Partnership for 21st Century Skills), "Framework for 21st Century Learning," pp. 1-2.

[2] E. Kostiainen, T. Ukskoski, M. Ruohotie-lyhty, M. Kauppinen, J. Kainulainen, and M. Tommi, "Meaningful learning in teacher education," Teach. Teach. Educ., vol. 71, pp. 66-77, 2018.

[3] B. E. Callahan and E. Dopico, "Science teaching in science education," Cult. Stud. Sci. Educ., vol. 11, no. 2, pp. 411-418, 2016.

[4] I. Jahnke, P. Bergström, E. Mårell-Olsson, L. Häll, and S. Kumar, "Digital Didactical Designs as research framework: iPad integration in Nordic schools," Comput. Educ., vol. 113, pp. 1-15, 2017.

[5] D. Goldman, D. Baum, O. Ayalon, and B. Weiss, "Influence of Green School Certification on Students' Environmental Literacy and Adoption of Sustainable Practice by Schools," J. Clean. Prod., 2018.

[6] J. Wang and M. Jou, "Computers in Human Behavior Qualitative investigation on the views of inquiry teaching based upon the cloud learning environment of high school physics teachers from Beijing, Taipei, and Chicago," Comput. Human Behav., vol. 60, pp. 212-222, 2016.

[7] D. K. Capps and B. A. Crawford, "Inquiry-Based Instruction and Teaching About Nature of Science: Are They Happening?" J. Sci. Teacher Educ., vol. 24, pp. 497-526, 2013.

[8] C. J. Wenning, "Assessing inquiry skills as a component of scientific literacy," J. Phys. Teach. Educ. Online, vol. 4, no. 2, pp. 1-32, 2007.

[9] M. Pedaste et al., "Phases of inquiry-based learning: Definitions and the inquiry cycle," Educ. Res. Rev., vol. 14, pp. 47-61, 2015.

[10] C. J. Wenning, "Professional knowledge standards for physics teacher educators: Recommendations from the CeMast Commission on NIPTE," J. Phys. Teach. Educ. Online, vol. 6, no. 1, pp. 2-7, 2011.

[11] C. J. Wenning, "Level of inquiry: Using inquiry spectrum learning sequences to teach science," J. Phys. Teach. Educ. Online, vol. 5, no. 4, pp. 11-20, 2010.

[12] C. J. Wenning, "The Levels of Inquiry Model of Science Teaching," J. Phys. Teach. Educ. Online, vol. 6, no. 2, pp. 9-16, 2011 .

[13] C. J. Wenning, "Levels of inquiry: Hierarchies of pedagogical practices and inquiry," J. Phys. Teach. Educ. Online, vol. 2, no. 3, pp. 3-11, 2005.

[14] C. J. Wenning, "Implementing inquiry-based instruction in the science classroom: A new model for solving the improvement-of-practice problem," J. Phys. Teach. Educ. Online, vol. 2, no. 4, pp. 9-15, 2005.

[15] C. J. Wenning, "A generic model for inquiry-oriented labs in postsecondary introductory physics," J. Phys. Teach.
Educ. Online, vol. 3, no. 3, pp. 24-33, 2006.

[16] L. B. Flick and N. G. Lederman, "Scientific Inquiry and Nature of Science: Implication for Teaching, Learning, and Teacher Education," in Science \& Technology Education Library, Netherlands: Springer, 2006.

[17] D. Cairns and S. Areepattamannil, "Exploring the Relations of Inquiry-Based Teaching to Science Achievement and Dispositions in 54 Countries," Res. Sci. Educ., pp. 1-23, 2017.

[18] C. J. Wenning, "Levels of inquiry: Hierarchies of pedagogical practices and inquiry processes," J. Phys. Teach. Educ. Online, vol. 2, no. 3, pp. 3-12, 2005.

[19] T. R. Guskey, Evaluating Professional Development. California: Corwin Press, Inc., 2000.

[20] N. Teig, R. Scherer, and T. Nilsen, "More isn't always better: The curvilinear relationship between inquiry-based teaching and student achievement in science," Learn. Instr., vol. 56, no. October 2017, pp. 20-29, 2018.

[21] L. Zhang, “'Hands-on' plus 'inquiry’? Effects of withholding answers coupled with physical manipulations on students' learning of energy-related science concepts," Learn. Instr., no. December 2017, pp. 0-1, 2018.

[22] C. Quintana et al., "A scaffolding design framework for software to support science inquiry," J. Learn. Sci., vol. 13, no. 3, pp. 337-386, 2004.

[23] J. J. Park, N. H. Choe, D. L. Schallert, and A. K. Forbis, "The chemical engineering research laboratory as context for graduate students' training: The role of lab structure and cultural climate in collaborative work," Learn. Cult. Soc. Interact., vol. 13, no. February, pp. 113-122, 2017.

[24] M. Simpson, "The Importance of Creativity on Our Global Society and in Today's Educational System," Baylor Univ., pp. 1-18, 1983.

[25] G. King, R. O. Keohane, and S. Verba, Designing Social Inquiry. New Jersey: Princeton University Press, 1995.

[26] L. Luginbuhl and D. Park, "Self-monitoring to minimize student resistance to inquiry," J. Phys. Teach. Educ. Online, vol. 5, no. 3, pp. 11-25, 2010.

[27] J. Dewey, How We Think: A Restatement of the Relation of Reflective Thinking to the Educative Process. Boston: D.C.Heath \& Co., 1910.

[28] C. J. Wenning, "Engaging students in conducting Socratic dialogues: Suggestions for science teachers," J. Phys. Teach. Educ. Online, vol. 4, no. 1, pp. 10-13, 2006. 